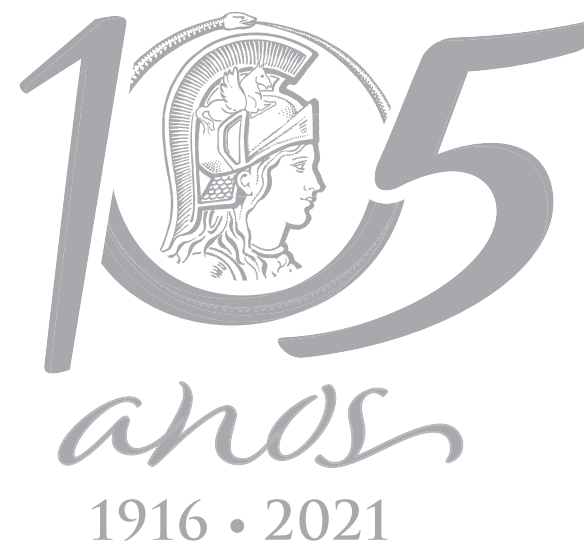

\title{
ANIMAL SCIENCE
}

\section{Biogeographic regionalization of the Neotropical region: New map and shapefile}

\author{
JUAN J. MORRONE, TANIA ESCALANTE, GERARDO RODRÍGUEZ-TAPIA, AYLÍN \\ CARMONA, MARCELO ARANA \& JORGE D. MERCADO-GÓMEZ
}

\begin{abstract}
We provide a map and shapefile of the 57 biogeographic provinces of the Neotropical region. Recognition of these provinces is based on their endemic species, but their delimitation on the map is based on ecoregions combining climatic, geological, and biotic criteria. These provinces belong to the Antillean, Brazilian and Chacoan subregions, and the Mexican and South American transition zones. We provide a vector file of the biogeographical regionalization by converting the map into a polygon shapefile and a raster file with all provinces.
\end{abstract}

Key words: biogeographic provinces, Neotropics, regionalization, transition zones.

\section{INTRODUCTION}

The Neotropical region comprises the tropical areas of South America, Central America, southern and central Mexico, and the Antilles (Morrone 2018). In the most recent biogeographic regionalization analyses, 57 provinces have been recognized (Morrone 2014, 2018, 2020, Martínez et al. 2017, Apodaca et al. 2019, Colli-Silva et al. 2019, Arana et al. 2021).

In addition to the different names that these provinces have received (see Morrone 2014), there is little agreement on their precise boundaries, especially when they span over different countries. This is a serious problem, because different authors may consider that they are referring to the same biogeographic province, but their units are not strictly comparable. To unify the different evolutionary biogeographic and ecoregional schemes into a single system, as done for Argentina (Arana et al. 2017, 2021) and Mexico (Morrone et al. 2017), we consider that the boundaries of the ecoregions combining climatic, geological, and biotic criteria with evolutionary units (areas of endemism) are appropriate. Thus, we provide herein a map of the biogeographic provinces of the Neotropical region (following Löwenberg-Neto 2014, Morrone 2014, 2017, 2018, 2020, Martínez et al. 2017, Morrone et al. 2017, Apodaca et al. 2019, ColliSilva et al. 2019, Arana et al. 2021), based on the ecoregions recognized by Olson et al. (2001), and the corresponding shapefile.

\section{MATERIALS AND METHODS}

The map is based on the modified shapefiles of the ecoregions of Olson et al. (2001) and the provinces of Löwenberg-Neto (2014), Morrone et al. (2017), Apodaca et al. (2019), Colli-Silva et al. (2019) and Arana et al. (2021). To facilitate future biogeographic analyses, we provide a vector file (shapefile; shp extension).

To draw the map, we used as base map the 'Terrestrial ecoregions of the world' (Olson et al. 2001), redrawing the biogeographic provinces with ArcMap v. 10.1 (ESRI 2012) and QGIS v. 2.16 .3 
(QGIS Development Team 2009). This conversion was made in three steps: (1) the geographic location of each province was based on the georeferenced shapefile called base map, (2) new polygons over province limits were created and (3) province names were inserted into the shapefile table.

In the first step, the Neotropical ecoregions were selected, excluding those that belong to the Nearctic and Andean regions sensu stricto (Morrone 2014, 2015). In the table of the ecoregion's shapefile, the names of the Morrone's regionalization (2014) were inserted for ecoregions with perfect correspondence with the provinces. For the Mexican Neotropical provinces, the polygons of Morrone et al. (2017) were merged to the ecoregion shapefile.

In the second step, we modified the boundaries of some ecoregions. Colli-Silva et al. (2019) proposed two provinces for the Brazilian 'campos rupestres'. The shapefile provided by Colli-Silva et al. (2019) was joined with the ecoregions layer, to incorporate this modification, dissolving and renaming the polygons. For the Colombian paramos, Jorge D. Mercado-Gómez provided a shapefile based on Beltrán et al. (2009), Morales et al. (2007), Schargel (2011), Jiménez-Rivillas et al. (2018) and Gil-Novoa et al. (2020), which was joined, dissolved, and renamed following Morrone (2021). The boundaries of the Esteros del Iberá province in Uruguay were based on Guerrero et al. (2018), Apodaca et al. (2019) and Elián L. Guerrero (pers. comm.), delimiting the polygons with the map of MVOTMA (2021), to represent Apodaca et al.'s (2019) Figure 16 on the map. Regarding the boundaries of the Argentinean provinces, we modified the vertices of some polygons according to Arana et al. (2021). For delineating the boundaries of the Mexican provinces extending to Central America, Morrone et al.'s (2017) polygons were merged with the ecoregions, assigning the forest ecoregions to the Chiapas Highlands province, and the southern lowlands ecoregions to the Pacific Lowlands province.

In the third step, individual shapefiles were generated for each one of the biogeographic provinces. For each polygon, we added the following information in the shapefile table: province name, and subregion or transition zone. Finally, we transformed the complete and individual shapefiles in raster format at a pixel resolution of 30 seconds of $\operatorname{arc}\left(\approx 1 \mathrm{~km}^{2}\right.$ at the Equator) to make them compatible with other sources in raster format (v. gr. Hijmans et al. 2005, Cuervo-Robayo et al. 2014).

\section{RESULTS}

The map of the biogeographic provinces is represented in Figure 1. These provinces are classified into three subregions, two transition zones and seven dominions:

Antillean subregion: the Antilles and the Bahamas Islands, with seven provinces (Morrone 2014, 2017).

Brazilian subregion: central and southern Mexico, Central America, and northwestern South America, including four dominions and 27 provinces (Morrone 2014, 2017).

Chacoan subregion: southeastern South America, with three dominions and 11 provinces (Morrone 2014, 2017, Colli-Silva et al. 2019, Arana et al. 2021).

Mexican Transition Zone: mountainous areas of Mexico, Guatemala, Honduras, El Salvador, and Nicaragua north of lake Nicaragua, with five provinces (Morrone 2014, 2017, 2020).

South American Transition Zone: Andean highlands between western Venezuela and Chile, desert areas of coastal Peru and northern Chile, and central western Argentina, with seven 


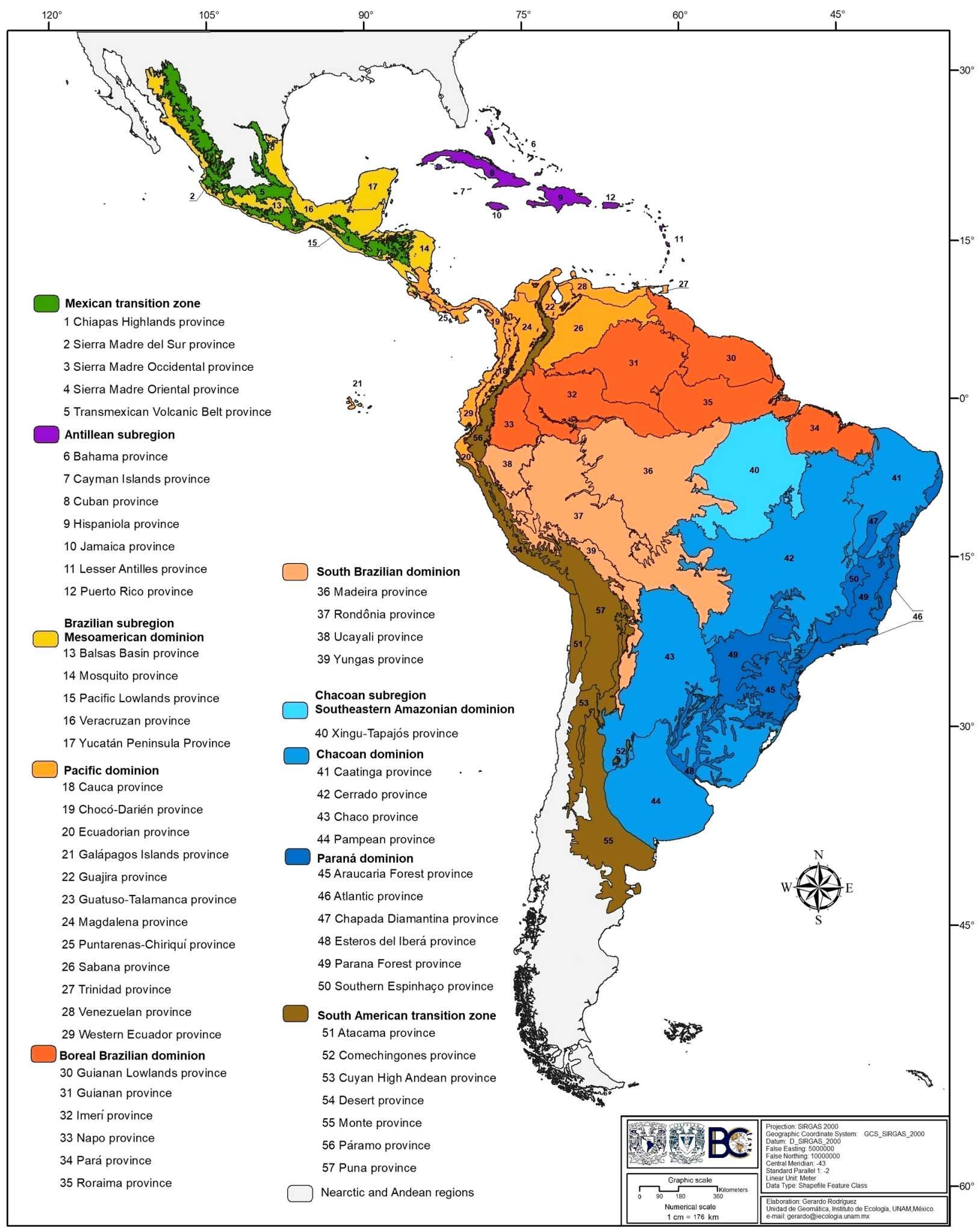

Figure 1. Biogeographic provinces of the Neotropical region. 
provinces (Morrone 2014, 2017, 2018, Martínez et al. 2017).

The map and metadata are freely available and may be downloaded at neotropicalmap. atlasbiogeografico.com. Maps are in vectorial and raster formats, both in SIRGAS2000 geographic projection for South America and in geographic coordinates.

\section{Acknowledgments}

This work was supported by the Programa de Apoyo a Proyectos de Investigación e Innovación Tecnológica (PAPIIT) from the Dirección General de Asuntos del Personal Académico de la Universidad Nacional Autónoma de México (DGAPA, UNAM) under grant IN218520

\section{REFERENCES}

APODACA MJ, KATINAS L \& GUERRERO EL. 2019. Hidden areas of endemism: Small units in the south-eastern Neotropics. Syst Biodivers 17: 425-438.

ARANA MD, MARTÍNEZ GA, OGGERO AJ, NATALE ES \& MORRONE JJ. 2017. Map and shapefile of the biogeographic provinces of Argentina. Zootaxa 4341: 420-422.

ARANA MD, NATALE E, FERRETI N, ROMANO G, OGGERO A, POSADAS P, MARTÍNEZ G \& MORRONE JJ. 2021. Esquema biogeográfico de la República Argentina. Opera Lilloana vol. 56, San Miguel de Tucumán, 238 p.

BELTRÁN K, SALGADO S, CUESTA F, LEÓN-YÁNEZ S, ROMO LEROUX K, ORTIZ E, CÁRDENAS A \& VELÁSTEGUI A. 2009. Distribución espacial, sistemas ecológicos y caracterización florística de los páramos en el Ecuador. EcoCiencia, Proyecto Páramo Andino and Herbario QCA, Quito, 54 p.

COLLI-SILVA M, VASCONCELOS TNC \& PIRANI JR. 2019. Outstanding plant endemism levels strongly support the recognition of campo rupestre provinces in mountaintops of eastern South America. J Biogeogr 46: 1723-1733.

CUERVO-ROBAYO A, TÉLLEZ-VALDÉS O, GÓMEZ-ALBORES MA, VENEGAS-BARRERA CS, MANJARREZ I \& MARTÍNEZ-MEYER E. 2014. An update of high-resolution monthly climate surfaces for Mexico. Int J Climatol 34: 2427-2437.

ESRI - ENVIRONMENTAL SYSTEMS RESOURCE INSTITUTE. 2012. ArcGIS Desktop Sofware, Release 10. Redlands, California.
GIL-NOVOA J, MORALES-PUENTES M \& MERCADO-GÓMEZ J. 2020. Biogeographic origins and floristic affinities of the bryophytes of the Tota-Bijagual-Mamapacha complex in the Páramos of Boyacá, Colombia. Phytotaxa 477: 171-193.

GUERRERO EL, APODACA MJ, DOSIL-HIRIART FD \& CABANILLAS PA. 2018. Análisis biogeográfico de los humedales del Sistema fluvial del Río de la Plata basado en plantas trepadoras y epífitas. Rev Mex Biodivers 89: 1190-1200.

HIJMANS RJ, CAMERON SE, PARRA JL, JONES PG \& JARVIS A. 2005. Very high resolution interpolated climate surfaces for global land areas. Int J Climatol 25: 1965-1978.

JIMÉNEZ-RIVILLAS C, GARCíA JJ, QUIJANO-ABRIL MA, DAZA JM \& MORRONE JJ. 2018. A new biogeographical regionalisation of the Páramo biogeographic province. Austr Syst Bot 31: 296-310.

LÖWENBERG-NETO P. 2014. Neotropical region: A shapefile of Morrone's (2014) biogeographical regionalization. Zootaxa 3802: 300.

MARTÍNEZ GA, ARANA MD, OGgERO AG \& NATALE ES. 2017. Biogeographical relationships and new regionalisation of high-altitude grasslands and woodlands of the Central Pampean Ranges (Argentina), based on vascular plants and vertebrates. Austr Syst Bot 29: 473-488.

MORALES M ET AL. 2007. Atlas de páramos de Colombia. Bogotá, Instituto de Investigación de Recursos Biológicos Alexander von Humboldt, p. 208.

MORRONE JJ. 2014. Biogeographical regionalisation of the Neotropical region. Zootaxa 3782: 1-110.

MORRONE JJ. 2015. Biogeographical regionalisation of the Andean region. Zootaxa 3936: 207-236.

MORRONE JJ. 2017. Neotropical biogeography: Regionalization and evolution. CRC Press, Taylor and Francis Group. Boca Raton, 282 p.

MORRONE JJ. 2018. Evolutionary biogeography of the Andean region. CRC Press, Taylor and Francis Group, Boca Raton, $250 \mathrm{p}$.

MORRONE JJ. 2020. The Mexican Transition Zone: A natural biogeographic laboratory to study biotic assembly. Springer, Cham, 191 p.

MORRONE JJ. 2021. Review of the subprovinces and districts of the Páramo biogeographic province, northern South America. Rev Mex Biodivers 92: 1-7.

MORRONE JJ, ESCALANTE T \& RODRÍGUEZ-TAPIA G. 2017. Mexican biogeographic provinces: Map and shapefiles. Zootaxa 4277: 277-279. 
MVOTMA. 2021. Humedales. Geoservicios. Montevideo: Ministerio de Vivienda, Ordenamiento Territorial y Medio Ambiente Sitio. https://www.ambiente.gub.uy/ geoservicios/.

OLSON DM ET AL. 2001. Terrestrial ecoregions of the world: A new map of life on Earth. Bioscience 51: 933-938.

QGIS DEVELOPMENT TEAM. 2009. QGIS Geographic Information System. Open Source Geospatial Foundation. URL http://qgis.osgeo.org.

SCHARGEL R. 2011. Una reseña de la geografía física de Venezuela, con énfasis en los suelos. BioLlania 10: 11-26.

\section{How to cite}

MORRONE JJ, ESCALANTE T, RODRÍGUEZ-TAPIA G, CARMONA A, ARANA M \& MERCADO-GÓMEZ JD. 2022. Biogeographic regionalization of the Neotropical region: New map and shapefile. An Acad Bras Cienc 94: e20211167. DOI 10.1590/0001-3765202220211167.

Manuscript received on August 20, 2021;

accepted for publication on September 11, 2021

JUAN J. MORRONE

https://orcid.org/0000-0001-5566-1189

\section{TANIA ESCALANTE}

https://orcid.org/0000-0002-9127-8969

\section{GERARDO RODRÍGUEZ-TAPIA ${ }^{3}$}

https://orcid.org/0000-0003-0953-7755

\section{AYLÍN CARMONA ${ }^{2}$}

https://orcid.org/0000-0002-5517-0416

\section{MARCELO ARANA ${ }^{4}$}

https://orcid.org/0000-0001-7921-6186

\section{JORGE D. MERCADO-GÓMEZ ${ }^{5}$}

https://orcid.org/0000-0002-4619-0028

${ }^{1}$ Museo de Zoología 'Alfonso L. Herrera', Facultad de Ciencias, Universidad Nacional Autónoma de México (UNAM), 04510 Mexico City, Mexico

${ }^{2}$ Grupo de Biogeografía de la Conservación, Facultad de Ciencias, Universidad Nacional Autónoma de México (UNAM), 04510 Mexico City, Mexico

${ }^{3}$ Unidad de Geomática, Instituto de Ecología, Universidad Nacional Autónoma de México (UNAM), 04510 Mexico City, Mexico

${ }^{4}$ Orientación Plantas Vasculares, Departamento de Ciencias Naturales, Facultad de Ciencias Exactas, Físico-Químicas y Naturales, Instituto ICBIA (UNRCCONICET), Universidad Nacional de Río Cuarto, Ruta 36 km 601, X5804ZAB Río Cuarto, Córdoba, Argentina

${ }^{5}$ Grupo Evolución y Sistemática Tropical, Departamento de Biología y Química, Universidad de Sucre, Carrera 28, No. 5-267, Barrio Puerta Roja, Sincelejo, Colombia

Correspondence to: Juan J. Morrone

E-mail:morrone@ciencias.unam.mx

\section{Author contributions}

Juan J. Morrone and Tania Escalante: conceptualization. Juan J. Morrone: writing of the original draft and editing of the final version. Tania Escalante, Gerardo Rodríguez-Tapia, Aylín Carmona, Marcelo Arana and Jorge D. Mercado-Gómez: formal analysis. All authors: review of the final version.

(c) BY 